\title{
Introducing a new support model for access control of road cargo vehicles at Brazilian ports through Radio Frequency Identification Technology (RFID)
}

\author{
Apresentando um novo modelo para controle de acesso de veículos de carga \\ rodoviária em portos brasileiros por meio da tecnologia de identificação \\ por radiofrequência
}

Roger Bittencourt ${ }^{[0]}$, Amir Mattar Valente ${ }^{[b]}$, Eduardo Lobo ${ }^{[c]}$

\footnotetext{
[a] Universidade Federal de Santa Catarina (UFSC), Fundação de Ensino e Engenharia de Santa Catarina (FEESC), Laboratório de Transportes e Logística (LabTrans), Florianópolis, SC, Brasil

[b] Universidade Federal de Santa Catarina (UFSC), Departamento de Engenharia Civil (ECV), Laboratório de Transportes e Logística (LabTrans), Florianópolis, SC, Brasil

[c] Universidade Federal de Santa Catarina (UFSC), Departamento de Ciências da Administração (CAD), Laboratório de Transportes e Logística (LabTrans), Florianópolis, SC, Brasil
}

\begin{abstract}
The present study regards the creation of a support model for access control and optimization of cargo loading at ports. It aims to minimize the deficiencies of port accesses and to optimize shipping rates, using an algorithm to create virtual queues and use Radio Frequency Identification (RFID) technology. The theoretical approach and some of the data reported in this paper came from a master's degree research project of one of the authors, through the Civil Engineering Graduate Program at the Federal University of Santa Catarina. The port chosen for implementing the proposed model was the Porto de Vitória, one of the busiest transportation terminals in Brazil. Initially, a survey was carried out locally and the data collected were tabulated to be used in a simulator. The results show the effectiveness of the model based on the use of a simulation system (Arena ${ }^{\circledR}$ ). The applied model helps to avoid traffic jams in the port area and also allows the automation of port access.
\end{abstract}

Keywords: Port logistics. RFID. Ports.

\section{Resumo}

Este artigo apresenta um estudo com vistas à criação de um modelo para o controle de acesso e também para a otimização do embarque de cargas nos portos brasileiros. O presente artigo visa apoiar a minimização de deficiências de acesso aos portos e também otimizar as taxas e custos de embarque, por meio da utilização de um algoritmo para criar filas virtuais, considerando ainda a utilização da tecnologia de identificação por radiofrequência, denominada RFID, do inglês radio frequency identification (RFID) technology. A abordagem teórica e alguns dos dados discutidos no âmbito desse trabalho provêm de uma dissertação de mestrado de um dos autores, na área da Engenharia Civil, no Programa de Pós-Graduação em Engenharia Civil da Universidade Federal de Santa Catarina. O porto escolhido para a implementação do modelo proposto foi o Porto de Vitória, o qual é um dos mais movimentados em termos de terminais de transporte no Brasil. Inicialmente, a pesquisa foi

RB is M.Sc., e-mail: roger.labtrans@gmail.com AMV is Dr., e-mail: amir.labtrans@gmail.com EL is Dr, e-mail: eduardo.lobo@ufsc.br 
realizada localmente e os dados coletados foram tabulados e tratados por meio de um simulador. Os resultados mostraram a efetividade do modelo, mediante o uso de um sistema de simulação (Arena ${ }^{\circledR}$ ). 0 modelo aplicado ajuda a evitar congestionamentos na área de acesso ao porto e, com isso, torna-se possível a automação do acesso ao porto.

Palavras-chave: Logística portuária. RFID. Portos.

\section{Introduction}

According to Lobo \& Valente (2014, p. 384):

In Transportation and Logistics field, it can be observed that the Brazilian State has been developing, in the past few years, strategies and planning, in order to provide minimal conditions, like the PNLT (National Plan of Logistics and Transportation) and PNLP (National Plan of Port Logistics), and other documents and policies.

These authors also affirm that it is known that consumption is concentrated in the urban centers, where there is more population, more resources and higher income. Therefore, internally, in any country of the globalized east, in order to supply its internal market, it is required an efficient link between production and consumption, which in turn, demands efficient logistics. Therefore, it can be assumed that efficiency could be addressed as an indicator for improvements.

In this paper, it is considered that efficient port operations can help society. Such efficiency can be reached through technological tools and also management tools, which allow for instance, route optimization, monitoring and supply and distribution control.

Lobo \& Valente (2014) conclude: it can be observed the availability of planning and production control systems integrated to the whole chain, added to the usability of the Supply Chain Management - SCM approach.

In this paper, authors explore the use of a support model for access control and optimization of cargo loading at ports. It aims to minimize the deficiencies of port accesses and to optimize shipping rates, using an algorithm to create virtual queues and use Radio Frequency Identification (RFID) technology.

According to data published by the SEP/PR (Special Department of Ports in Brazil) in 2010, the country has a navigable coast of eight-thousand and five-hundred kilometers, where approximately seven-hundred million tons of several different types of goods are transported annually. Long-course navigations account for transporting over $90 \%$ of Brazil's total exports, as well as for a good amount of the imports. Moreover, their transportation cost is one of the lowest among all the transportation modes in Brazil (SEP, 2010).

The port system in Brazil currently consists of 37 public ports, comprehending both maritime and river ports. Out of this total, 18 are either delegated, conceded or have their operation authorized by the administration of state and municipal governments. There are yet another 42 private use terminals (TUPs) and three port complexes under concession to the private sector.

The infrastructure issues concerning road accesses in the current Brazilian port panorama compromise their operational efficiency, making the road accesses an obstacle to the country's economic and social development. One of the alternatives to make the adaptation of the port system viable for the current needs regards the use of new technologies that may optimize the access of vehicles to the ports (Valente, 2008).

The application of a logistic port model that uses technological innovation, specifically RFID technology, may be an efficient alternative to mitigate the issues hereby reported and also to rationalize the flow of vehicles on the roads, making it as minimal as possible. The possibility to sequence the cargo offers the advantage of reducing costs related to internal container transportation and also shortening the ships' departure and arrival times.

\section{Perspective of the Brazilian ports}

According to the Infrastructure Report published in April 2011 by the CNI, the country's National Industry Confederation, Brazil would have to invest approximately 40 billion Reais in infrastructure within the next 10 years to solve the current infrastructure issues (CNI, 2011). 
Container transportation is chiefly related to the geographical condition of the port sector. According to Rodrigues (2007), Porto de Santos in the State of São Paulo, stands out for the highest concentration of industries in Brazil, and Porto de Rio Grande in the State of Rio Grande do Sul, stands out for its proximity to MERCOSUL.

An analysis of the whole year of 2010 shows that container transportation in all the organized ports and private use terminals (TUPs) of the country was of 6.822.657 TEUs, which represents an increase of $12 \%$ in comparison to 2009 , and a decrease of $3 \%$ in comparison to 2008 (Table 1). However, the improvements in the productivity of ports in Brazil are still considered insufficient when compared with the productivity of ports in more developed countries. Another remarkable aspect is that the TUPs have been increasing their participation in the port market share year after year, showing that the investments throughout the private sector are growing substantially, and they now show a higher increment than that of public investments. Such investments allow the TUPs to quickly increase their operating capacities.

Figure 1 shows that in December 2008 the total amount of cargo transported through the TUPs, including the public ports selected for the research carried out by the CNI, was of approximately 26 million tons, of which $66 \%$ were transported through the TUPs, and $34 \%$ through public ports.

In December 2010, the total amount of cargo transported was approximately 38 million tons, an increase of $45 \%$ compared to 2008 ; the participation of the ports in this total decreased to $26 \%$ (CNI, 2011).

Another issue that has been substantially aggravated in Brazil is the waiting time for docking and departure of container ships. In 2010, over 850 ship stopovers were canceled; 393 more than in 2009.

Container ships are responsible for over 30 thousand stopovers a year in Brazil and for $75 \%$ of the country's international trade. According to the CNI, the total time spent in such operations in 2010 was 4.000 days, considering the hours of stoppages, which were mostly caused by excess traffic at the terminals. For instance, the financial loss caused only in Porto de Santos in 2010 was US\$ 95 million. Such loss occurs throughout the entire logistical chain, raising the Brazil-cost ${ }^{1}$ (CNI, 2011).

The amount of containers transported only by Porto de Santos, that is the largest Port in Brazil, has increased $215 \%$ in the past 10 years, and with the recovery of the international economy after the 2008 crisis, the number of containers transported has been rapidly increasing which explains the frequent traffic jams at Brazilian ports (Portos e Navios, 2011).

According to Tovar \& Ferreira (2006, p. 209), for the Brazilian port system to start contributing as a promoter of international trade strengthening, it is extremely important to create conditions for a sustained development of the waterway and roadway infrastructure in the port areas, once the lack of maintenance dredging and the roadway and railway accesses are the greatest obstacles for an effective development of the port system.

It is known that the roadway and railway networks to access the ports are inefficient, and that they compromise the integrity and safety of the cargo, impair competitiveness among ports and increase costs. Likewise, the internal transit roads of the ports are in poor conditions. Their lack of parking lots and maneuver areas, hinder cargo transportation, and cause jams with trucks and trains inside and outside the port area and, mainly, on the urban roads of the city, increasing cargo waiting and moving time, thus raising the final cost of waterway transportation.

The projects established for the improvement of the infrastructure of roadway and railway accesses to ports, established in the Growth Acceleration Program - Stages 1 and 2 (PAC1 and PAC2) of the Brazilian government, cannot be discontinued. The National Port Logistical Plan (PNLP), developed by the Transportation Laboratory - LabTrans of the Federal University of Santa Catarina - UFSC, for the Special Department of Ports of the Presidency of the Republic - SEP/PR, must present measures, projects, and the list of the main projects for the accesses to the ports that must be carried out to meet current and future port demands.

\footnotetext{
${ }^{1}$ The term Brazil-Cost is used to refer to the set of structural, bureaucratic and economic difficulties that may turn away investments in Brazil, making national development more difficult, increasing unemployment and generating informal jobs, tax evasion, and capital flight. It is seen as a set of factors that compromise the competitiveness and efficiency of the country's industry.
} 
Table 1 - Comparative table of container transportation

\begin{tabular}{cccccc}
\hline \multicolumn{1}{c}{ Year } & $\mathbf{2 0 0 8}$ & $\mathbf{2 0 0 9}$ & $\mathbf{2 0 1 0}$ & $\mathbf{2 0 1 0 / 2 0 0 9}(\%)$ & $\mathbf{2 0 1 0 / 2 0 0 8 ~ ( \% ) ~}$ \\
\hline $\begin{array}{l}\text { Containers (thousand TEUs) / Ports } \\
\text { Organized + TUPs }\end{array}$ & 6,999 & 6,108 & 6,823 & 12 & -3 \\
\hline
\end{tabular}

Source: Adapted from CNI (2011).

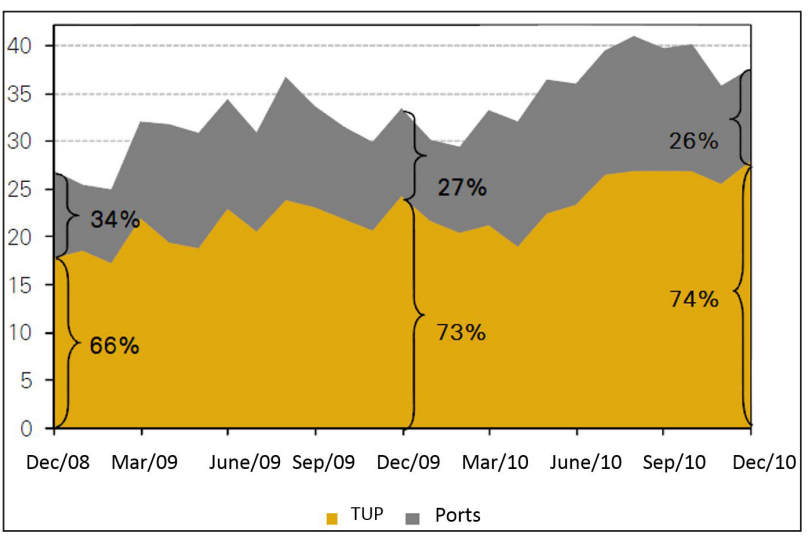

Figure 1 - Total amount of cargo transported. Private use terminals and selected ports (million $t$ )

Source: CNI (2011).

Note: TUPS - Ponta da Madeira/state of Maranhão, Tubarão/state of Espirito Santo, Almirante Barroso/state of São Paulo, Porto de Trombetas/state of Pará, Mannus/state of Amazonas, Madre de Deus/state of Bahia.

Ports - Santos/SP, Paranaguá/state of Paraná, Vila do Conde/state of Pará, Rio Grande/state of Rio Grande do Sul, Itaqui//state of Maranháo, Suape/state of Pernambuco, São Francisco do Sul/state of Santa Catarina, Aratu/state of Bahia.

Current situation of the logistical model of cargo transportation at the ports

The logistical port model for shipment and reception of cargo currently used in most of the ports consists in the creation of time windows, where shippers send their cargo to the port according to the time stipulated by the port operator. Thus, access control is impaired, since shippers eventually send their cargo either at the same time, in truck fleets, or before the time scheduled to ensure the delivery of the merchandises, since traffic conditions are uncertain.

Another issue caused by such model is the generation of container transportation inside a primary area. Because of this time window, the goods do not arrive to the ships in their loading order, requiring much more handling of container piles to place them in same the order that they will be loaded onto the ship.

Hence, there are issues that are external and internal to the ports;

- External, with the increase of traffic in access roadways and the increase of queues, urban mobility becomes more difficult;

- Internal, because of the queues generated and the lack of cargo sequencing, there is a need for internal organization, requiring, for example, a stock of containers, making loading to ships more difficult.

Despite the economic measures established by the PAC (Growth Acceleration Program, Brazil), the evolution in international maritime transportation, the variety and quantity of departure and arrival of cargo, along with the complexity of port operations have generated the resurgence of queues, thus causing an economic impact on the productivity and quality of the services provided.

Within such context, operational research becomes an indispensable tool for the construction of a model that may be used as an analysis and comprehension tool, aiming to make decisions that enable the improvement of a measure, such as a measure against traffic jams in the port system (Andrade, 2009), for instance.

Since RFID technology has been widely and successfully used in distant areas, working especially as a locating tool, such technology may also be applied for the control of the port system, especially in relation to control arrival and departure of cargo vehicles.

Considering the items mentioned above, and seeking to optimize and improve the port system, the present work aims to address the development of a new support model for cargo access and control, as described below. 


\section{Description of the model}

The model proposed, evaluated by Bittencourt (2012), is composed of computer systems that must be developed and installed at the ports, such as: a concentrating system for receiving and processing the booking of the ships and the cargo, a computerized system for sequencing of cargo and creation of a virtual queue, a computer system for cargo scheduling, and access control system at the entry and the exit gates, using RFID tags.

The main systems, according to Bittencourt (2012), are described below (Figure 2):

- Data concentrating system: This system will receive information from the ship owners, crew officers, shippers and others via EDI (Electronic Data Interchange). The most important pieces of information to be received are: the order of loading cargo onto the ships, especially the order of container loading, and the information related to the cargo (type and location);

- $\quad$ Sequencing system and virtual queue: This system uses advanced expertise in queuing theory. A sequencing of cargo will be carried out based on the information received regarding the order of the ships; the virtual traffic queue will be generated based on the information of locations

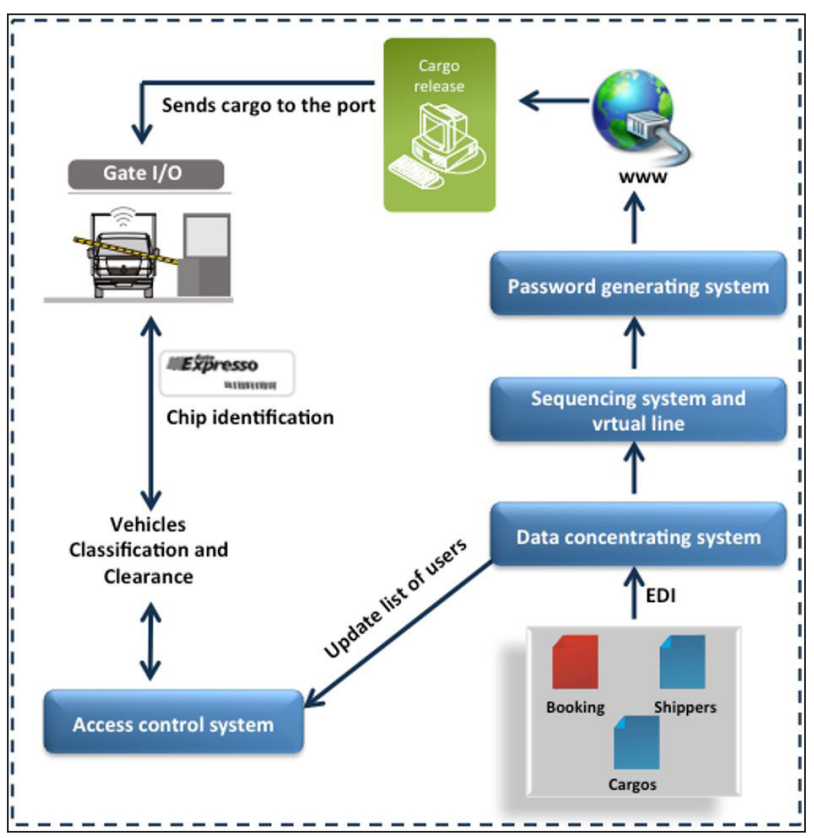

Figure 2 - Graphic description of the proposed model Source: prepared by the authors, 2012. provided by the crew officers. This system will also be capable of real time processing so the cargo always arrives in the correct order, as well as to perform adjustments according to potential non-conformities, such as delays in arrival, miss the deadline to obtain a password, etc;

- $\quad$ Password generating system: It is a Web-based system that allows crew officers to know the date and time that their ships are to be dispatched and inform the port what driver and vehicle is transporting them. These data are connected to an RFID tag, which will be read at the entry gates of the ports;

- Access control system: antennas for reading the RFID tags set in the vehicles will be placed at the entry gates.

The general sequence of model operation occurs in the following steps:

1) Collection of information regarding the order of the cargo that must enter the ship (booking), and the location of the crew officers (cargo);

2) Information processing and creation of the virtual queue;

3) Through the Web system, a password is generated, the crew officer informs the staff, date and time of arrival at the port, and;

4) In the port area, the access to the control system checks through RFID if the vehicle is within the scheduled time (Figure 2). In this last stage, antennas for reading the RFID tags set in the vehicles will be installed at the entry gates. The control system will check the information related to the tag with the date and the time established for the arrival, according to the schedule set in the sequencing system, and the creation of the virtual queue. When the identification is positive, the gate is lifted, and the cargo enters the port.

\section{Methodology}

\section{Port identification}

The identification of the port that was object of the present study and provided the application of the proposed model was divided into three stages. The first 
stage was the tabulation and selection of seven ports with the largest amount of cargo transportation in Brazil. The second stage encompassed the selection of only two ports, which are objects of further studies.

After the identification of two ports for the present study, in the third stage, the analysis was performed considering the following premises:

- Level of access control already in use at the port;

- Level of urbanization in the surrounding areas;

- Issues related to access to ports, and;

- Analysis of the impact of the issue related to access of roadway cargo on the economy of the town and of the state.

In addition to the interviews carried out in the ports and warehouses, a complete inspection of the surroundings of the ports was carried out, and images available on the Internet were collected for visualization of the map and evaluation of the exact location of the roads and the roadway access.

\section{Main criteria}

The criteria adopted to analyze data are the following: Average of trucks/day when the port operates at maximum capacity; Average of buses/day that arrive at the port; Average of passenger vehicles/day that arrive at the port; Number of port terminals; Transportation rate of the main port terminal in relation to the others; Number of entry gates; Average waiting time at the entry gate for trucks operating with bulk using a pre-identification fixed on the windshield of the trucks; Average waiting time at the entry gate for trucks operating containers; Average waiting time at the entry gate of the Terminal in Vila Velha - TVV; Average waiting time at the exit gate of the TVV; Maximum occupancy of trucks in the internal parking lot of the TVV; Average maximum size of the queue of trucks waiting to enter the port; Average of containers/day at the TVV terminal; Number of hours that the cargo needs to stay at the TVV before departure; Maximum number of days for the removal of vehicles in the Peiú terminal; Percentage of passenger vehicles at rush hours.
Analysis of the collected data

After subjected to a detailed survey, data collected were tabulated and analyzed in order to construct the model for the problem solution. To perform the analysis and confirm the efficacy of the model proposed, two simulation systems were tested, namely, Arena ${ }^{\circledR}$ and Aimsun ${ }^{\circledR}$, which are capable of performing the modeling of the current problem and of new scenarios.

Study regarding access capacity, and application of the logistical model

To create the scenario in the simulator, it was necessary to check the access capacity of roadways and, in some cases, propose the appropriate changes to avoid traffic jams in the accesses. Also, it was checked whether such roads would withstand the future projection of cargo arriving at the port.

Based on the main scenario, which represents the current reality of the ports, the efficacy of the simulator and the reliability of data collected in the interviews were confirmed. Thereafter, several other scenarios were built, then with the addition of the new proposed model into the simulator. Further simulations were carried out using the new scenarios, demonstrating their applicability in port logistics.

\section{Solution survey}

When carrying out the simulations of all the scenarios created in the simulator, were detected potential changes in the infrastructure that are required for the adoption of the new model. The adoption of a buffer or a parking lot may be necessary according to the simulator. Another change that may be detected with the use of the simulator is the number of entry gates at the ports.

\section{Model application}

Firstly, the Brazilian ports with higher transportation operations were pointed out through the ANTAQ - the country's Annual Abstract of Statistics of the National Department of Waterway Transportations. In this 
first stage, it was possible to point out the ports of Santos, in the State of São Paulo, Paranaguá in the State of Paraná, São Francisco do Sul in the State of Santa Catarina, Itajaí also in Santa Catarina, Rio de Janeiro in the State of Rio de Janeiro, Rio Grande in the State of Rio Grande do Sul and finally Vitória in the State of Espírito Santo (ANTAQ, 2009).

In the second stage, only two ports were selected for a more detailed evaluation. Among the ports identified in the first stage, the port of Vitória in the State of Espírito Santo was generally considered the least efficient and the worst in relation to roadway access, according to the evaluation carried out by the Brazilian crew officers (CEL, 2007). Based on these considerations, the port was chosen to participate in the third stage of the selection.

During the inspections at the ports, Porto de Itajaí was the one that showed the best performance, having minimized traffic jam issues with trucks in the town's access roads. This because of the implementation of a cargo triage system, and the local authorities actively supervising the traffic queues and preventing illegal parking.

On the other hand, Porto de Vitória showed some issues regarding roadway access. The port is surrounded by a densely populated area (Figure 3), requiring an urgent solution to allow it to be competitive and to improve its operation level.

\section{Collected data}

Below, there are the main data collected in the interviews and that were used for the development of the scenarios during the inspection at Porto de Vitória (Table 2).

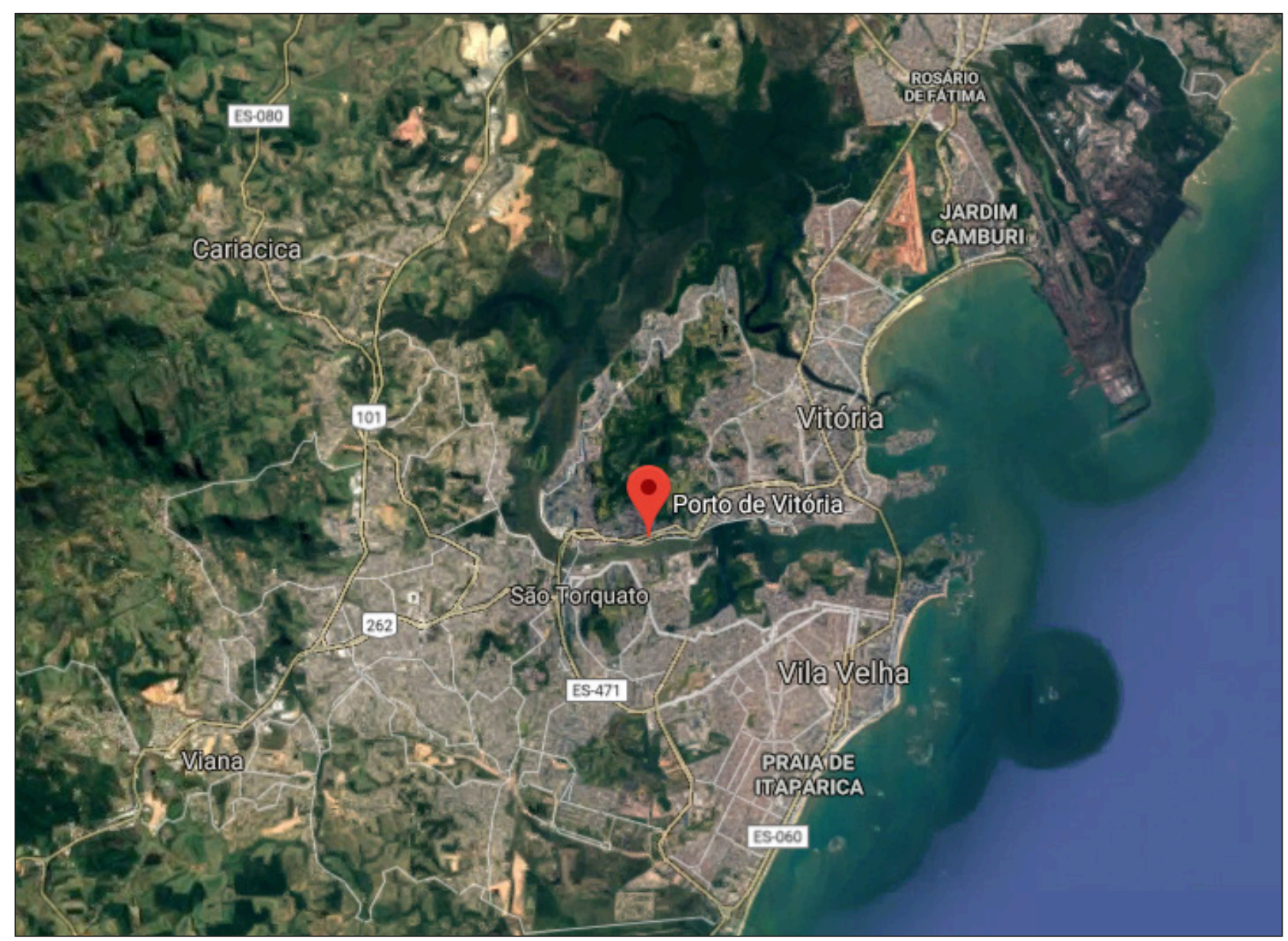

Figure 3 - Satellite photo of the cities of Vitória and Vila Velha Source: Google Maps (2018). 
Table 2 - Data obtained in the interviews carried out at Porto de Vitoria

\begin{tabular}{lc}
\hline \multicolumn{1}{c}{ Description } & Amount \\
\hline Average of trucks/day when the port operates at maximum capacity & 1,293 \\
Average of buses/day that arrive at the port & 41 \\
Average of passenger vehicles/day that arrive at the port & 753 \\
Number of port terminals & $40 \%$ \\
Transportation rate of the main port terminal in relation to the others & 1 \\
Number of entry gates & $30^{\prime \prime}$ \\
Average waiting time at the entry gate for trucks operating with bulk using a pre-identification fixed on the windshield of \\
the trucks
\end{tabular}

Source: Prepared by the authors, 2012.

There are also data on Table 3, after Equation 1, which is related to the Equivalence of trucks and passenger vehicles for the calculation of the percentage of time stopped in two ways and in one way, separately (Ec and Vr).

Capacity and service level of land access

For the analysis of the traffic on the road of Capuaba, an access road to Porto de Capuaba, the methodology used was the one approved by the National Department of Transportation Infrastructure - DNIT, in the "Manual of Traffic Studies," edited in 2006 by the IPR - Institute of Roadway Researches.

The daily amount of traffic established for the road of Capuaba in its critical level of use for all the terminals is 1.239 trucks per day, plus 753 passenger vehicles and 41 buses that also enter the port daily.

Considering that $10 \%$ trucks, and $50 \%$ automobiles enter at rush hours, and using the equivalence factor of 1.1, the flow entering the port per lane in equivalent vehicles will be of $258.65 \mathrm{ucp} / \mathrm{h} / \mathrm{lane}$, as shown in the calculation presented below, on Equation 1:

$$
\begin{array}{ll}
\text { Traffic flow per hour } & (1,239+41) \times \\
\text { in one way per lane } & =\frac{0.10 \times 1.1+(753 \times 0.50)}{2}=258.65 \mathrm{ucp} / \mathrm{h} / \text { lane }
\end{array}
$$

Adopting an operation speed between 20 and $25 \mathrm{~km} / \mathrm{h}$, based on the graphic below (Figure 4), it will result in an operation between the areas of service levels B and $\mathrm{C}$, adequate for operation with an intense flow of trucks.

However, if the access to the port remains at its current situation, with only one traffic lane, the operation conditions for the amount of vehicles of 517.3 ( $2 \times 258.65)$ will be restricted to service level $\mathrm{E}$, which is close to the level that indicates traffic jams.

\section{Identification of the port access}

In order to identify and quantify the issue at Porto de Vitória, inspections and interviews were carried out with several people involved. It was possible to see that there are serious issues especially trucks 
Table 3 - Equivalence of trucks and passenger vehicles for the calculation of the percentage of time stopped in two ways and in one way, separately (Ec and $\mathrm{Vr}$ )

\begin{tabular}{ccccc}
\hline $\begin{array}{c}\text { Type of } \\
\text { vehicle }\end{array}$ & $\begin{array}{c}\text { Flow of vehicles in the two } \\
\text { ways (Ucp/h) }\end{array}$ & $\begin{array}{c}\text { Flow of vehicles in one way } \\
\text { (Ucp/h) }\end{array}$ & Flat Terrain & Corrugated Terrain \\
\hline \multirow{2}{\text{Truck}}{} & $0-600$ & $0-300$ & 1.1 & 1.8 \\
Ec & $>600-1200$ & $>300-600$ & 1.1 & 1.5 \\
& $>1200$ & $>600$ & 1.0 & 1.0 \\
\hline
\end{tabular}

Source: DNIT (2006).

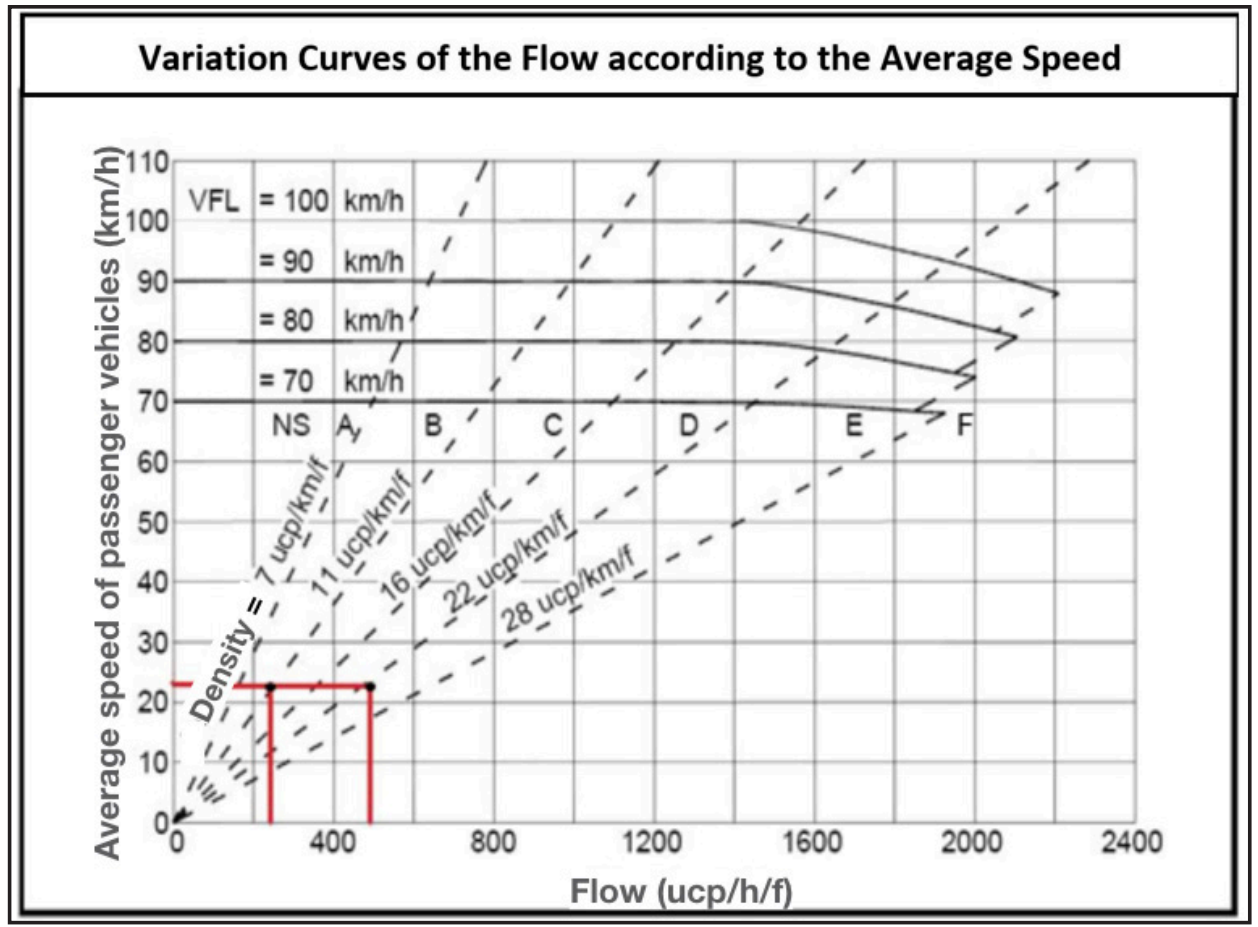

Figure 4 - Representation of the service level through variation areas Source: DNIT (2006).

illegally parked along the road causing changes in the flow of vehicles at the port and considerably decreasing the traffic capacity in the area. Another issue detected was the use of part of the port access road which encompasses 2 of the 4 lanes available for the traffic of vehicles of local residents.

\section{Simulations}

Two simulation systems available on the market and largely used for simulations of processes and traffic, Arena ${ }^{\circledR}$ and Aimsun ${ }^{\circledR}$ respectively, were compared before being applied for analysis. The Arena ${ }^{\circledR}$ system showed to be more appropriate for the construction of the scenarios and for obtaining the results. The Aimsun ${ }^{\circledR}$ system, on the other hand, has shown better visually but limited regarding construction of parking lots and access control. The basic scenario, which abstractly represents the reality of the issues regarding access to the port, was created with the use of Arena ${ }^{\circledR}$.

With the information collected at Porto de Vitória and in the proposed model, a simulator to reproduce the current situation and create new scenarios was used. Thus, to perform the simulations, the software Arena ${ }^{\circledR}$ was used, since it is specialized in 
abstracting processes in simulation models. Such tool has efficiently assisted in decision making, creating and testing experiments predicting what will take place, without effectively changing anything in the physical environment. From the survey carried out at Port of Vitória, it was concluded that the problem was not on the port access road, since the flow of vehicles per hour was below the capacity of the port (Capuaba road). In this way, the location of the terminals and the respective travel time until the port were disregarded. With this, only the processes of attendance of the vehicles that arrive at the port complex were analyzed. The simulation time was set up to run along 3 days (observed as the maximum of terminals overload time) and with 1.000 replications for each scenario. Based on the results of the analysis, it was possible to select the best solution for the issue.

\section{Conclusion}

Considering the results obtained, it may be concluded that for the application of RFID technology, especially of the new model in other ports, it will be necessary to evaluate the current infrastructure conditions, mainly as to the number of entry gates and the conditions of the access roads. Further simulations may be necessary to indicate when and where infrastructure improvements are required, as well as the size of the buffer according to the cargo transportation rate at each port.

The role of RFID in this research was the key to reducing the waiting time to enter or exit by $40 \%$ and allows to control the travel time of goods near the Port. Simulations showed that in the worst case (all terminals operating at the same time) the length of the truck queue would be reduced from 2 kilometers to 100 meters. Anyway, it may be stated that RFID technology can be used to generate efficiency and efficacy gains and that it is a basis for the development and application of new models for port operations.

It is important to note that, in addition to technical and operational questions related to each port and its surroundings, qualitative aspects that involve political, environmental, and social aspects must be considered in new studies, even though they were not object of the present work. For those new studies, it is recommended the model to include cargos that enter the port by railway or through waterways, on barges. The cargos that come in through such modes, may compete with the roadway mode, generating a competition for port efficiency and port infrastructure for loading and unloading.

Another point that may be further investigated is the creation of an algorithm using the concept of the theory of queues, probability and artificial intelligence for the creation of a fully automated virtual queue, capable of self-calibration according to the information generated throughout the process.

To conclude and ratify the perspective of operation management, it is important to note that the technological innovation, applied to Transportation and Logistics, is a sine qua non to generate competitiveness gains and, in the case of Brazil, to reduce the Brazil-cost and consequently draw new investments in infrastructure and also promote economic growth and social development.

\section{References}

Agência Nacional de Transportes Aquaviários - ANTAQ. (2009). Anuário Estatístico. Retrieved in 2009, September 1 , from http://antaq.gov.br/Portal/Anuarios/Portuario2009/ Index.htm

Andrade, E. L. (2009). Introdução à pesquisa operacional: métodos e modelos para análise de dados. Rio de Janeiro: LTC.

Bittencourt, R. (2012). Modelo de apoio ao controle de acesso de veículos pelo modal rodoviário junto aos portos utilizando tecnologia RFID (Dissertação de mestrado). Universidade Federal de Santa Catarina, Florianópolis.

Departamento Nacional de Infraestrutura de Transportes - DNIT. (2006). Manual de Estudos de Tráfego. Rio de Janeiro: DNIT.

Centro de Estudos em Logística - CEL. Instituto de Pósgraduação e Pesquisa em Administração - COPPEAD. (2007). Logistical Panorama - management of roadway transportation of loads in corporations - Practices and tendencies. Rio de Janeiro: CEL/COPPEAD.

Confederação Nacional da Indústria - CNI. (2011). Relatório de Infraestrutura (Vol. 8, No. 3). Brasília: CNI.

Google Maps. 2018. Retrieved in 2018, May 15, from https://www.google.com.br/maps/place/Porto de Vitória

Lobo, E., \& Valente, A. M. (2014). Brazilian cargo road transportation infrastructure: globalization, logistics, policy and growth. Acta Scientiarum, 36(3), 381-387. http://dx.doi.org/10.4025/actascitechnol.v36i3.18843. 
Portos e Navios. (2011). Cancelamento de escalas nos portos quase dobra em 2010 devido aos gargalos. Retrieved in 2009, September 1, from https://www.portosenavios.com. $\mathrm{br} /$ noticias/portos-e-logistica/cancelamento-de-escalasnos-portos-quase-dobra-em-2010-devido-aos-gargalos

Rodrigues, P. R. A. (2007). Introdução aos sistemas de Transporte no Brasil e à Logística Internacional (4. ed., 242 p.). São Paulo: Aduaneiras.

Secretaria de Portos - SEP. (2010). Departamento de Portos. Retrieved in 2009, September 1, from http://www. portosdobrasil.gov.br/sistema-portuario-nacional
Tovar, A. C. A., \& Ferreira, G. C. M. (2006). A Brazilian port infrastructure: the current Model and perspectives for its sustained development. Revista do BNDES, 13(25), 209-230.

Valente, A. M. (2008). Transporte rodoviário de cargas. In A. M. Valente, E. Passaglia, J. A. Cruz, J. C. Mello, N. A. Carvalho, S. Mayerle, \& S. Santos. Qualidade e produtividade dos transportes (233 p.). São Paulo: Cengage Learning.

Received: Apr. 08, 2017

Approved: Oct. 28, 2017 